\title{
Soluble Calcium-Activated Nucleotidase 1
}

National Cancer Institute

\section{Source}

National Cancer Institute. Soluble Calcium-Activated Nucleotidase 1. NCI Thesaurus. Code C97377.

Soluble calcium-activated nucleotidase 1 (401 aa, $\sim 45 \mathrm{kDa}$ ) is encoded by the human CANT1 gene. This protein plays a role in nucleotide hydrolysis. 